Swarthmore College

Works

$12-1-2003$

\title{
Measures Of Restrictions On Inward Foreign Direct Investment For OECD Countries
}

Stephen S. Golub

Swarthmore College, sgolub1@swarthmore.edu

Follow this and additional works at: https://works.swarthmore.edu/fac-economics

Part of the Economics Commons

Let us know how access to these works benefits you

\section{Recommended Citation}

Stephen S. Golub. (2003). "Measures Of Restrictions On Inward Foreign Direct Investment For OECD Countries". OECD Economic Studies. Issue 1. 88-122. DOI: 10.1787/eco_studies-v2003-art3-en https://works.swarthmore.edu/fac-economics/5

This work is brought to you for free by Swarthmore College Libraries' Works. It has been accepted for inclusion in Economics Faculty Works by an authorized administrator of Works. For more information, please contact myworks@swarthmore.edu. 


\title{
MEASURES OF RESTRICTIONS ON INWARD FOREIGN DIRECT INVESTMENT FOR OECD COUNTRIES
}

\author{
Stephen S. Golub
}

\section{TABLE OF CONTENTS}

Introduction .

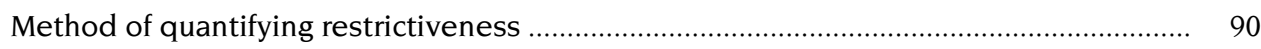

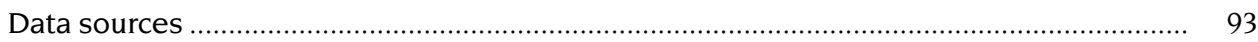

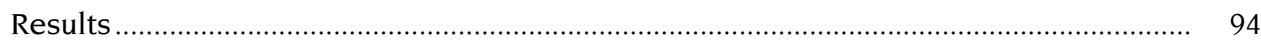

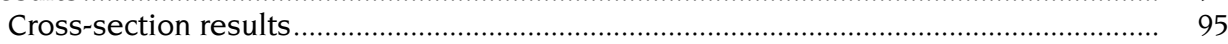

Time series results ................................................................................. 105

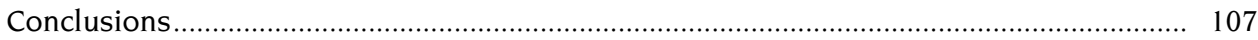

Annex I. Comparisons with Hardin and Holmes (1997) ............................................ 110

Annex II. Sensitivity analysis to changes in assumptions ............................................. 112

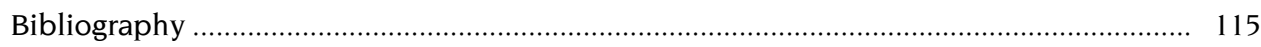

Consultant, OECD Economics Department and Professor of Economics, Swarthmore College United States (email: sgolub1@swarthmore.edu). The author thanks the following OECD colleagues for comments and encouragement: Guiseppe Nicoletti, Michael Feiner, Jørgen Elmeskov, Sven Blöndal, Peter Jarrett, Andrew Dean, Mark Pearson, Eva Thiel, Hans Christiansen, Paul Schieder, Pierre Sauvé, Dana Hajkova, Kwang-Yeol Yoo, Daniel Mirza, Michael Freudenberg, and Michael Gestrin. I also benefited from discussions at the WTO with Bijit Bora and at UNCTAD with Zbigniew Zimny, James Zhan, Torbjorn Fredriksson and Abraham Negash, and from correspondence with Edward Graham and Stephen Yeaple. Martine Levasseur and Janice Gabela provided efficient help in putting the paper together. The opinions expressed in this paper are personal and do not engage the OECD or its member countries. 


\section{INTRODUCTION}

Attitudes and policies towards liberalisation of international capital flows in general and foreign direct investment (FDI) in particular have been subject to considerable controversy and flux (OECD 2002a). Recognition of the economic benefits afforded by freedom of capital movements sometimes clash with concerns about loss of national sovereignty and other possible adverse consequences. FDI, even more than other types of capital flows, has historically given rise to these conflicting views, because FDI involves a controlling stake by often large multinational corporations (MNCs) over which domestic governments, it is feared, have little power. The controversies have mostly focused on inward FDI, due to sensitivity about foreign control over domestic industry. In the last few years, outward FDI from OECD countries to developing countries has also been the focus of criticism by NGOs and others who view such FDI as a cause of depressed labour and environmental standards. For an effective rebuttal of such criticisms of outward FDI, see Graham (2000).

Countries facing increased inflows of FDI have often experienced unease. Many developing countries have until recently been wary of inward FDI. Even in the United States, the surge of Japanese FDI in the 1980s led to widespread concerns about excessive foreign control and adverse effects on national security, as expressed in the popular press, and in legislative action. ${ }^{1}$ Critics of inward FDI argue that there are adverse economic and political effects on the host country. The alleged economic effects include balance of payments deficits, reduced domestic research and development, diminished competition, crowding-out of domestic firms and lower employment. Economic analysis has shown that most of the alleged economic drawbacks of FDI are of little merit (Graham and Krugman 1995). FDI has little long-run effects on employment and the trade balance, as these are determined by macroeconomic factors. While negative microeconomic effects on domestic competition and local research and development are conceivable, FDI inflows are more likely to enhance competition and local technical capabilities. Indeed, most studies suggest that the benefits of inward FDI are substantial (OECD 2002c). FDI is a form of international economic integration that brings gains to both parties according to the principle of comparative advantage. In contrast to international trade which involves arms' length transactions, FDI involves intra-firm trade and transactions in intangible assets such as 
knowledge and reputation. Beyond the standard gains from trade, FDI inflows can provide dynamic gains from technology transfer and skill-building. These benefits are especially important in developing countries where foreign technology and managerial expertise are lacking. As a source of outside capital, FDI has been seen increasingly as advantageous relative to portfolio flows, due to the instability of the latter.

The political concerns relating to threats to national security and excessive political influence exerted by foreign firms are of possibly greater validity, although Graham and Krugman (1995) argue that these too are sometimes exaggerated. In times of war, foreign ownership of strategic industries by enemy countries poses a clear danger to national security, but the practical import of this consideration is negligible today, given that FDI flows occur overwhelmingly among friendly countries. A more serious danger is the potentially adverse effects of foreign control of industries important for defence capability. This issue is further complicated by the difficulties of identifying such industries, given dual-use civilian and military technologies, e.g. for electronics and aviation. To the extent that FDI increases efficiency of such industries, however, it could also enhance domestic defence capability, and in any case the number of industries involved is limited. High levels of FDI could also be associated with increased political pressure from foreign interest groups. While there may be some negative consequences associated with lobbying by foreign firms, these are usually no worse than those associated with pressures from domestic special interest groups. A much more diffuse argument is that foreign control of high profile industries such as airlines and telecommunications disturbs nationalistic sensitivities. Satisfying such non-economic predilections must be balanced against the economic cost of restrictions on FDI.

Overall, economic analysis suggests that with rare exceptions the appropriate policy towards FDI is neutrality between foreign and domestic firms, neither favouring nor discriminating against foreign investors. Neutrality involves both right of establishment for foreign firms and national treatment of such firms once they are established. Right of establishment signifies that there are no discriminatory obstacles to foreign green-field investment or mergers and acquisitions. National treatment involves non-discrimination in conducting business. Thus, from an economic point of view, both discriminatory restrictions and special incentives are of questionable merit, at least in developed countries with well-functioning markets.

Notwithstanding any remaining concerns about the adverse effects of FDI, there can be little doubt that the general trend has been towards liberalisation, especially in the past two decades. Throughout the world, policymakers have increasingly been persuaded of the merits of inward FDI in terms of employment, capital and especially transfer of technology. Consequently, many countries have 
reduced restrictions on FDI and adopted incentives to encourage FDI (UNCTAD 1996). Still, some restrictions remain in place even in countries that generally welcome FDI.

This paper focuses on the nature and extent of these restrictions in OECD countries and their evolution over time. It attempts to classify and quantify discrimination against foreign firms regarding right of establishment and national treatment. There are several important reasons for such a study. First, there is little comprehensive information on national policies towards FDI. In contrast to tariff, and even non-tariff barriers to trade, there have been very few studies quantifying restrictions on FDI. The existing literature is discussed below.

Second, and related, information on the extant barriers to FDI could be helpful for international negotiations of investment rules. There have been a number of recent initiatives aimed at formulating international investment agreements (Box 1), although these suffered a blow with the failure of the Multilateral Agreement on Investment (MAI) at the OECD in 1998. According to Graham (2000, p. 187), greater knowledge of the costs and benefits of liberalisation of investment would be conducive to the success of such negotiations. Of course, the nature and magnitude of the restrictions in force is a starting point for any such calculations of costs and benefits.

Third, restrictions on FDI are identified as a key variable in the recent theoretical knowledge-capital model of the multinational corporation (Markusen and Maskus, 2001). In this literature, as in previous models of the MNC, firms choose where to produce according to the costs and benefits of alternative locations. Barriers to FDI raise the costs of foreign investment. In econometric tests of the knowledge-capital model, researchers have used measures based on surveys of investor opinion reported in the World Competitiveness Report, rather than objective measures. Although these subjective measures are usually statistically-significant in FDI regressions, it is also useful to develop objective indicators that are comparable across countries and over time. This paper is part of a larger OECD project on the determinants of FDI (Nicoletti et al. 2003). The effects of the computed restrictions on FDI patterns are studied in Nicoletti et al. but are not discussed in this paper.

FDI restrictions are but one of a set of policies that discriminate between foreign and domestic inventors. Corporate taxes have been the focus of considerable research and a comprehensive study for OECD countries is presented in Yoo (2003). It would also be highly desirable to assemble information about specific FDI incentives, but such information is even more difficult to obtain than for FDI restrictions and falls beyond the scope of the present study.

A serious drawback is that the present study is primarily limited to overt 88 restrictions on FDI, mostly ignoring non-policy institutional restrictions, such as 


\section{Box 1. International investment agreements}

Formal international agreements on foreign direct investment are far less extensive than on international trade, despite the importance of FDI in the world economy. However, the 1990s have seen a substantial rise in the number of bilateral investment protection treaties, and regional and bilateral trade agreements in which investment disciplines figure prominently. These agreements include NAFTA, the recent agreements concluded by Singapore with EFTA, Japan and Australia and the Association Agreement between the European Community and Chile. The European Union had already completely liberalised intra-EU capital movements in the late 1980s.

The OECD has been an important actor in international discussions and agreements on FDI.* At present the OECD Code of Liberalisation of Capital Movements forms the only multilateral framework in force on international capital flows, including FDI. Under the Code, countries bind themselves to agreed measures liberalising capital movements. Moreover, under the OECD Declaration on International Investment and Multinational Enterprises, the 30 OECD countries and 7 non-OECD adhering countries are committed to accord national treatment to foreign enterprises operating in their territories and to encourage their multinational enterprises to engage in responsible business conduct in a variety of areas.

There are several investment-related provisions in the agreements related to the World Trade Organisation. The Uruguay Round led to an agreement on Trade Related Investment Measures (TRIMS) that restricts inter alia domestic-content requirements. The General Agreement on Trade in Services (GATS) covers all modes of service delivery, including "commercial presence" which is closely related to FDI. The GATS commitments, however, apply only to industries where countries have explicitly agreed to open their markets to foreign providers. In 1996, the WTO also created the Working Group on the Relationship Between Trade and Investment, a forum for discussion among WTO countries. At the Doha Ministerial Conference in November 2001, the WTO members agreed on the principle of undertaking negotiations on a multilateral framework after the 2003 WTO ministerial meeting at Cancun (see OECD 2002b).

* Further discussion of OECD experience with investment rules and multilateral initiatives concerning FDI can be found at www.oecd.org/daf/investment and in Graham (2000), Robertson (2002) and Sauvé and Wilkie (2000).

the nature of corporate governance, as well as policies that indirectly impinge on FDI, notably economic and social regulation. In some instances, however, allegations of government obstruction to foreign investment were considered. Despite these limitations, the present study is the most comprehensive to date in terms of country, time and sectoral coverage of FDI restrictions. 


\section{METHOD OF QUANTIFYING RESTRICTIVENESS}

In this section the method of quantifying restrictions is discussed. There are several issues involved in computing the restriction scores. A classification of various types of restrictions and a system of weighting are needed. These tasks are greatly complicated by the disparate nature of restrictions across countries and the inconsistent reporting of these restrictions. Sometimes it is difficult to determine the exact nature and incidence of a particular restriction without detailed knowledge of a country's productive structure and regulatory environment. Given the difficulties in classifying and ranking the various restrictions, some studies such as Sauvé and Steinfatt (in progress) and Hoekman (1995) are limited to counting the number of restrictions. While this has the advantages of simplicity and lack of arbitrariness, some restrictions are more important than others. For example, a ban on foreign ownership is much more restrictive than a screening or reporting requirement. It therefore seems preferable to attempt to weight different restrictions according to their significance, even though such a procedure surely entails some arbitrary judgements and errors.

This study adopts a variant of the methodology of the Australian Productivity Commission (APC) which carried out a similar study for the APEC countries, Service Trade and Foreign Direct Investment (Hardin and Holmes 1997, 2002, referred to hereafter as $\mathrm{HH}$, available at www.pc.gov.au/ic/research/information/servtrad/index.html). In the $\mathrm{HH}$ study, indices for FDI restrictions were calculated for 15 APEC countries for 11 service sectors, as classified by the GATS.

There have also been a number of other studies of restrictions on trade in services, mostly also by the APC, for particular service sectors (for example NguyenHong 2000, Kalirajan 2000, a number of studies in Findlay and Warren 2000, and the survey by McGuire 2002). Most APC and other studies present two sets of measures of restrictions: 1) domestic, i.e. limitations on market access for all firms and 2) foreign, i.e. discrimination against foreign firms in the form of limitations on national treatment or most favoured nation (MFN). Here, however, the focus is limited to the latter. Non-discriminatory policies that affect market access and operations for both domestic and foreign firms are not barriers to FDI per se. Also, these domestic barriers are incorporated in the other policies considered in the quantitative analysis of FDI for which these calculations were undertaken, and would duplicate these other indicators. An exception, however, was made for state-owned monopolies, which by their very nature preclude foreign ownership, and were considered to be tantamount to a ban on foreign investment.

Restrictions on foreign ownership are the most obvious barriers to establishment for FDI. They typically take the form of limiting the share of companies' equity capital in a target sector that non-residents are allowed to hold, e.g. to less 90 than 50 per cent, or even prohibit any foreign ownership. Examples of majority 
domestic ownership requirements include airlines in the European Union and North American countries, telecommunications in Japan, and coastal and freshwater shipping in the United States. Exclusive domestic ownership is also often applied to natural resource sectors with the aim of giving citizens access to the associated rents. For example, foreign ownership is banned in the fishing and energy sectors in Iceland, and in the oil sector in Mexico.

Obligatory screening and approval procedures can also be used to limit FDI though their constraining effects depend on the implementation of such practices. Stipulations that foreign investors must show economic benefits can increase the cost of entry and therefore may discourage the inflow of foreign capital. Such provisions apply, for instance, for a few industries in Japan and for the acquisition of more than 49 per cent of any existing enterprise in Mexico. Prior approval of FDI, such as mandated for all FDI projects in a few OECD countries, could also limit foreign capital inflow if it is taken as a sign of an ambivalent attitude towards free FDI, even though it may not be vigorously enforced. Simple pre- or post-notification (as required in e.g. Japan) is, however, unlikely to have much direct impact on capital inflows, but could have a negative signalling effect.

Other formal restrictions that can discourage FDI inflows include constraints on the ability of foreign nationals either to manage or to work in affiliates of foreign companies and other operational controls on these businesses. Stipulations that nationals or residents must form a majority of the board of directors, as in insurance companies in member countries of the European Union, in financial services industries in Canada and in transport industries in Japan, may undermine foreign owners' control over their holdings and hence make them more hesitant to invest under such circumstances. Similarly, if regulations restrict the employment of foreign nationals (as e.g. in Turkey), investors may judge that they cannot make use of the necessary expertise to make their investment worthwhile. Also, operational requirements, such as the restrictions vis-à-vis non-members on cabotage in most European Union countries for maritime transport may limit profits of foreignowned corporations, and hence the amount of funds foreign investors are willing to commit.

Apart from the formal barriers discussed above, FDI flows can be held back by opaque informal public or private measures. Indeed, claims abound that such practices are used systematically to limit foreign ownership of domestic businesses. Thus, the US Special Trade Representative (2003) has frequently stated that the system of corporate control in Japan has hampered investment by US companies and that regulatory practices in telecommunications in the European Union work as de facto FDI restraining measures. Similarly, Japanese Ministry of Economy, Trade, and Industry (2003) claims that FDI in financial services in the United States is restricted by the diverse and complex set of regulations at the state level and that barriers relating to interconnections hamper foreign entry into 
highly in view of the fact that foreign ownership is a necessary and essential condition for FDI. Screening and limitations on management are generally less important. Also, non-linearities are built into the scoring system to reflect the idea that a total ban on foreign ownership is significantly more restrictive than allowing a small foreign equity stake. Similarly, requiring an investor to demonstrate economic benefits is much more stringent than quasi-automatic approval, which in turn is considerably more demanding than simple notification. Other restrictions include constraints on the nationality or residency of executives and managers, duration of permissible work permits for expatriate executives, input restrictions, and miscellaneous other restrictions, such as discriminatory government regulations or approval processes. See Annex I for further discussion and a comparison with the $\mathrm{HH}$ weighting system.

Restrictiveness is calculated at the industry level and then a weighted-average is obtained using FDI and trade weights. The inclusion of trade flows in the weighting scheme is meant to partially alleviate the problem of endogeneity associated with FDI weights: highly restricted sectors will tend to experience less FDI. OECD and EU average restrictions are simple averages of country scores. Annex II further discusses the sectoral weights and provides some sensitivity analysis.

\section{DATA SOURCES ${ }^{2}$}

GATS Commitments. ${ }^{3} \mathrm{HH}$ and most other studies of restrictions on trade in services use the GATS commitments as their primary database, supplemented by other sources. The GATS schedules (WTO, 2002) are well organised, easy to understand, and authoritative. There is a close connection between the GATS classification of services and those used in this project (Table 2). As HH and others note, a limitation of the GATS commitments is that they are mostly "positive" in nature, i.e. they are commitments to open markets. This is in contrast to "negative" lists of exceptions to liberalisation. A problem with the GATS positive lists is that the absence of a positive commitment in some sector cannot necessarily be construed as a restriction. A country may simply have failed to list this sector in its schedule. Or, if the sector is restricted, GATS may be silent on the nature of the restriction. A more obvious limitation of the GATS schedules is that they only cover the service sectors. While services are undoubtedly the most highly restricted sectors, there are some restrictions in other sectors too.

OECD Code of Liberalisation and related OECD documents. ${ }^{4}$ The OECD Code of Liberalisation of capital movements contains a succinct list of "reservations" for FDI (item I-A in the Code). This Code has the advantage of being "negative", i.e. any non-listed sectors can be assumed free of restrictions, and are thus not subject to the ambiguity of interpretation as in the GATS. Also, the Code covers all sectors, 
Table 2. Correspondence between OECD FDI project, GATS and Australian Productivity Commission studies in the service sectors

\begin{tabular}{|c|c|c|}
\hline OECD FDI project & GATS and Hardin-Holmes & Australian Productivity Commission studies ${ }^{1}$ \\
\hline Real estate and business & Business services & Accounting, architectural, legal, engineering \\
\hline Post and telecommunication & Communication services & Telecommunications \\
\hline Construction & Construction & n.a. \\
\hline $\begin{array}{l}\text { Wholesale and retail trade, } \\
\text { repairs }\end{array}$ & $\begin{array}{l}\text { Distribution (wholesale, } \\
\text { retail) }\end{array}$ & Distribution \\
\hline Financial intermediation & Finance & Banking \\
\hline Transport and storage & Transport & Maritime transport \\
\hline Hotels and restaurants & Tourism & n.a. \\
\hline \multicolumn{3}{|l|}{$\begin{array}{l}\text { Memo: Other GATS and Hardin } \\
\text { Education } \\
\text { Environmental } \\
\text { Health and social services } \\
\text { Recreation, culture and spor } \\
\text { Other (repairs) }\end{array}$} \\
\hline \multicolumn{3}{|c|}{$\begin{array}{l}\text { 1. Covers all countries in OECD FDI project except for the Czech Republic, Hungary, Iceland and Poland. n.a. indicates } \\
\text { no study is available. } \\
\text { 2. Hardin and Holmes's study covered all GATS sectors except for "Other". } \\
\text { Source: OECD, GATS and Australian Productivity Commission studies in the service sectors. }\end{array}$} \\
\hline
\end{tabular}

not just services. A further major advantage of the Code is that it is possible to construct a time series of restrictions as the Code goes back to the 1960s (OECD 1992, 1987, 1982). In addition, the results were cross-checked against reservations submitted by member countries in the course of the negotiations for the Multilateral Agreement on Investment (MAI).

Other sources. The United States Special Trade Representative (USTR), Japanese Ministry of Economy, Trade and Industry (METI), and the European Union (EU) issue analyses of barriers to trade and FDI in their major partners and these are available on the internet (see references). An additional source is a CD from Price-Waterhouse-Coopers (2001) that Wei (2000) has used in his research on FDI. The Australian Productivity Commission has made available on its website a comprehensive tabulation of all of its sector-specific findings for a large group of countries, which includes almost all OECD countries. ${ }^{5}$

\section{RESULTS}

It should be again acknowledged that despite efforts to rely on multiple sources and objective reports, there is inevitably an arbitrary and subjective 94 aspect to some dimensions of the scoring. In particular, hidden institutional or 
behavioural barriers to FDI are very difficult to ascertain and quantify and the scoring reported here mostly ignores such barriers. A case in point is the allegation that the Japanese market is difficult to enter due to covert collusion between government and kereitsu business groups. Some attempt to include such hidden barriers was made, if such arguments are noted and documented in the USTR, METI or EU reports, but these received relatively little weight in relation to the statutory barriers, given the difficulties of quantifying these allegations. ${ }^{6}$ Also, the extent of enforcement of statutory restrictions is difficult to determine and was not factored into the calculations. The stringency of screening requirements could be particularly variable across countries.

It is possible that some countries are more forthcoming than others in selfreporting their restrictions. It could then be that more transparent countries receive higher scores, not because they are in fact more restrictive, but because they are more complete in their reporting.

Finally, reported restrictions are not standardised and there are difficulties in evaluating idiosyncratic restrictions in individual countries and putting them into context. For example, the United States does not have a direct limitation on foreign investment in telecommunications but instead has equity restrictions on companies holding broadcast and common carrier radio licenses. According to several sources (the European Union, PriceWaterhouseCoopers), this is an important de facto restriction on foreign investment in US telecoms, particularly for mobile telephony. There are numerous such instances requiring judgements about the relative severity of restrictions, given that this study covers 28 countries, 9 sectors, and 11 sub-sectors.

FDI restrictions can be either across-the-board, applying to all sectors, or sector-specific. The limitations on foreign equity levels are usually specified on an industry-by-industry basis, whereas notification and authorisation requirements are usually across-the-board.

The sectoral scores were aggregated with a combination of import and FDI weights, as noted earlier (the "adjusted FDI" weights in Table A.2). See Annex II for more detail and a comparison to value-added weights.

\section{Cross-section results}

Overall scores. A full set of FDI restrictions measures for 28 OECD countries were determined for the period 1998-2000. Table 3 presents the detailed results and Figure 1 provides an overview. Panel A of Figure 1 presents the baseline results, while Panel B excludes the effect of screening as an alternate measure, in view of the difficulties of assessing the impact of screening. There have been important changes in some countries since 2000 that are not reflected in the results. In the 
Table 3. Indices of FDI restrictions, 1998-2000

\begin{tabular}{|c|c|c|c|c|c|c|c|c|c|c|c|c|c|c|}
\hline & Australia & Austria & Belgium & Canada & $\begin{array}{c}\text { Czech } \\
\text { Republic }\end{array}$ & Denmark & Finland & France & Germany & Greece & Hungary & Iceland & Ireland & Italy \\
\hline \multicolumn{15}{|l|}{ Business services } \\
\hline Legal & 0.200 & 0.225 & 0.025 & 0.225 & 0.125 & 0.125 & 0.110 & 0.036 & 0.025 & 0.025 & 0.100 & 0.325 & 0.025 & 0.025 \\
\hline Accounting & 0.200 & 0.575 & 0.025 & 0.225 & 0.450 & 0.125 & 0.110 & 0.036 & 0.025 & 0.069 & 0.100 & 0.325 & 0.025 & 0.025 \\
\hline Architecture & 0.200 & 0.175 & 0.025 & 0.225 & 0.150 & 0.025 & 0.110 & 0.036 & 0.025 & 0.025 & 0.100 & 0.325 & 0.025 & 0.025 \\
\hline Engineering & 0.200 & 0.225 & 0.025 & 0.225 & 0.150 & 0.025 & 0.110 & 0.036 & 0.025 & 0.025 & 0.100 & 0.325 & 0.025 & 0.025 \\
\hline Total & 0.200 & 0.300 & 0.025 & 0.225 & 0.219 & 0.075 & 0.110 & 0.036 & 0.025 & 0.036 & 0.100 & 0.325 & 0.025 & 0.025 \\
\hline \multicolumn{15}{|l|}{ Telecommunications } \\
\hline Fixed & 0.492 & 0.375 & 0.375 & 0.625 & 0.550 & 0.075 & 0.290 & 0.251 & 0.275 & 0.425 & 0.400 & 1.000 & 0.125 & 0.075 \\
\hline Mobile & 0.200 & 0.225 & 0.075 & 0.225 & 0.550 & 0.075 & 0.110 & 0.251 & 0.075 & 0.125 & 0.100 & 0.325 & 0.125 & 0.075 \\
\hline Total & 0.419 & 0.338 & 0.300 & 0.525 & 0.550 & 0.075 & 0.245 & 0.251 & 0.225 & 0.350 & 0.325 & 0.831 & 0.125 & 0.075 \\
\hline Construction & 0.200 & 0.175 & 0.025 & 0.225 & 0.100 & 0.025 & 0.110 & 0.025 & 0.025 & 0.025 & 0.100 & 0.325 & 0.025 & 0.025 \\
\hline Distribution & 0.200 & 0.258 & 0.092 & 0.225 & 0.050 & 0.092 & 0.160 & 0.125 & 0.092 & 0.125 & 0.117 & 0.392 & 0.075 & 0.092 \\
\hline \multicolumn{15}{|l|}{ Finance } \\
\hline Insurance & 0.200 & 0.275 & 0.075 & 0.275 & 0.150 & 0.075 & 0.330 & 0.119 & 0.119 & 0.119 & 0.150 & 0.765 & 0.119 & 0.119 \\
\hline Banking & 0.300 & 0.175 & 0.075 & 0.575 & 0.150 & 0.075 & 0.110 & 0.075 & 0.075 & 0.119 & 0.100 & 0.325 & 0.075 & 0.175 \\
\hline Total & 0.277 & 0.198 & 0.075 & 0.506 & 0.150 & 0.075 & 0.161 & 0.085 & 0.085 & 0.119 & 0.112 & 0.427 & 0.085 & 0.162 \\
\hline Hotels and restaurants & 0.200 & 0.175 & 0.025 & 0.225 & 0.050 & 0.025 & 0.110 & 0.025 & 0.025 & 0.025 & 0.100 & 0.325 & 0.025 & 0.025 \\
\hline \multicolumn{15}{|l|}{ Transports } \\
\hline Air & 0.500 & 0.615 & 0.425 & 0.625 & 0.350 & 0.157 & 0.242 & 0.201 & 0.207 & 0.257 & 0.400 & 0.457 & 0.157 & 0.201 \\
\hline Maritime & 0.500 & 0.307 & 0.157 & 0.375 & 0.200 & 0.157 & 0.454 & 0.369 & 0.207 & 0.257 & 0.400 & 0.325 & 0.069 & 0.157 \\
\hline Road & 0.200 & 0.414 & 0.130 & 1.000 & 0.200 & 0.163 & 0.154 & 0.072 & 0.080 & 0.503 & 0.188 & 0.380 & 0.069 & 0.122 \\
\hline Total & 0.437 & 0.432 & 0.240 & 0.590 & 0.250 & 0.158 & 0.320 & 0.250 & 0.180 & 0.309 & 0.355 & 0.381 & 0.098 & 0.164 \\
\hline Electricity & 0.700 & 0.615 & 0.275 & 0.725 & 1.000 & 0.775 & 0.860 & 1.000 & 0.525 & 1.000 & 0.600 & 1.000 & 1.000 & 1.000 \\
\hline Manufacturing & 0.200 & 0.175 & 0.025 & 0.225 & 0.050 & 0.025 & 0.110 & 0.025 & 0.025 & 0.025 & 0.100 & 0.325 & 0.025 & 0.025 \\
\hline TOTAL & 0.270 & 0.268 & 0.091 & 0.352 & 0.171 & 0.087 & 0.177 & 0.111 & 0.084 & 0.130 & 0.164 & 0.390 & 0.074 & 0.097 \\
\hline
\end{tabular}

Source: See section on data sources. 
Table 3. Indices of FDI restrictions, 1998-2000 (cont.)

\begin{tabular}{|c|c|c|c|c|c|c|c|c|c|c|c|c|c|c|}
\hline & Japan & Korea & Mexico & Netherlands & $\begin{array}{c}\text { New } \\
\text { Zealand }\end{array}$ & Norway & Poland & Portugal & Spain & Sweden & Switzerland & Turkey & $\begin{array}{c}\text { United } \\
\text { Kingdom }\end{array}$ & $\begin{array}{l}\text { United } \\
\text { States }\end{array}$ \\
\hline \multicolumn{15}{|l|}{ Business services } \\
\hline Legal & 0.250 & 0.100 & 0.525 & 0.025 & 0.125 & 0.119 & 0.225 & 0.075 & 0.125 & 0.119 & 0.100 & 0.250 & 0.025 & 0.050 \\
\hline Accounting & 0.250 & 0.275 & 0.400 & 0.025 & 0.125 & 0.119 & 0.175 & 0.119 & 0.119 & 0.119 & 0.075 & 1.000 & 0.025 & 0.050 \\
\hline Architecture & 0.250 & 0.075 & 0.225 & 0.025 & 0.125 & 0.069 & 0.075 & 0.075 & 0.075 & 0.069 & 0.075 & 0.150 & 0.025 & 0.050 \\
\hline Engineering & 0.250 & 0.075 & 0.225 & 0.025 & 0.125 & 0.069 & 0.075 & 0.075 & 0.075 & 0.069 & 0.075 & 0.150 & 0.025 & 0.050 \\
\hline Total & 0.250 & 0.131 & 0.344 & 0.025 & 0.125 & 0.094 & 0.138 & 0.086 & 0.099 & 0.094 & 0.081 & 0.425 & 0.025 & 0.050 \\
\hline \multicolumn{15}{|l|}{ Telecommunications } \\
\hline Fixed & 0.750 & 0.525 & 0.425 & 0.185 & 0.525 & 0.469 & 0.675 & 0.351 & 0.275 & 0.469 & 0.375 & 1.000 & 0.025 & 0.350 \\
\hline Mobile & 0.250 & 0.525 & 0.325 & 0.025 & 0.125 & 0.069 & 0.675 & 0.351 & 0.275 & 0.169 & 0.075 & 0.450 & 0.025 & 0.550 \\
\hline Total & 0.625 & 0.525 & 0.400 & 0.145 & 0.425 & 0.369 & 0.675 & 0.351 & 0.275 & 0.394 & 0.300 & 0.863 & 0.025 & 0.400 \\
\hline Construction & 0.150 & 0.075 & 0.325 & 0.025 & 0.125 & 0.069 & 0.075 & 0.075 & 0.075 & 0.069 & 0.075 & 0.250 & 0.025 & 0.050 \\
\hline Distribution & 0.150 & 0.325 & 0.242 & 0.025 & 0.125 & 0.119 & 0.175 & 0.142 & 0.125 & 0.069 & 0.092 & 0.350 & 0.092 & 0.050 \\
\hline \multicolumn{15}{|l|}{ Finance } \\
\hline Insurance & 0.150 & 0.375 & 0.325 & 0.119 & 0.125 & 0.119 & 0.100 & 0.169 & 0.207 & 0.119 & 0.125 & 0.250 & 0.119 & 0.150 \\
\hline Banking & 0.200 & 0.475 & 0.325 & 0.075 & 0.125 & 0.119 & 0.325 & 0.175 & 0.163 & 0.119 & 0.125 & 0.250 & 0.075 & 0.150 \\
\hline Total & 0.188 & 0.452 & 0.325 & 0.085 & 0.125 & 0.119 & 0.273 & 0.174 & 0.173 & 0.119 & 0.125 & 0.250 & 0.085 & 0.150 \\
\hline Hotels and restaurants & 0.150 & 0.075 & 0.375 & 0.025 & 0.125 & 0.069 & 0.075 & 0.075 & 0.075 & 0.069 & 0.075 & 0.150 & 0.025 & 0.050 \\
\hline \multicolumn{15}{|l|}{ Transports } \\
\hline Air & 0.650 & 0.475 & 0.500 & 0.257 & 0.625 & 0.569 & 0.375 & 0.307 & 0.501 & 0.301 & 0.475 & 0.450 & 0.201 & 0.550 \\
\hline Maritime & 0.250 & 0.425 & 0.525 & 0.157 & 0.225 & 0.469 & 0.375 & 0.307 & 0.401 & 0.301 & 0.525 & 0.550 & 0.201 & 0.650 \\
\hline Road & 0.150 & 0.225 & 0.372 & 0.080 & 0.125 & 0.407 & 0.175 & 0.138 & 0.075 & 0.219 & 0.175 & 0.342 & 0.025 & 0.280 \\
\hline Total & 0.362 & 0.399 & 0.484 & 0.174 & 0.337 & 0.489 & 0.333 & 0.271 & 0.365 & 0.284 & 0.434 & 0.473 & 0.164 & 0.539 \\
\hline Electricity & 0.150 & 1.000 & 1.000 & 1.000 & 1.000 & 0.819 & 1.000 & 0.825 & 0.575 & 0.569 & 1.000 & 1.000 & 0.025 & 0.500 \\
\hline Manufacturing & 0.150 & 0.075 & 0.025 & 0.025 & 0.125 & 0.069 & 0.075 & 0.075 & 0.075 & 0.069 & 0.075 & 0.150 & 0.025 & 0.050 \\
\hline TOTAL & 0.230 & 0.260 & 0.273 & 0.083 & 0.189 & 0.182 & 0.213 & 0.157 & 0.165 & 0.140 & 0.172 & 0.338 & 0.064 & 0.169 \\
\hline
\end{tabular}

Source: See section on data sources. 
Figure 1. FDI restrictions in OECD countries, 1998-2000 ${ }^{1}$

\section{A. Baseline FDI restrictions ${ }^{2}$}

0.4 0.4

0.3

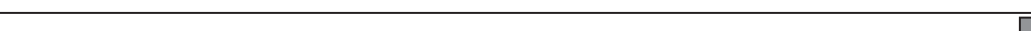

0.2

0.1

0

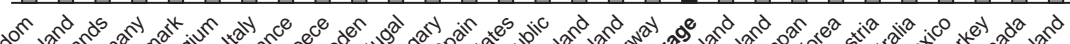

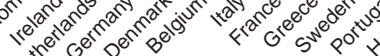

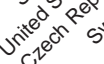

$0<e_{0}$

B. FDI restrictions (excluding screening requirements)

0.4

0.2

0.1

0

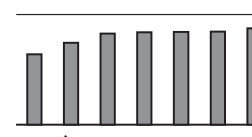

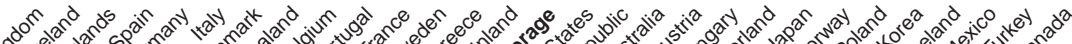

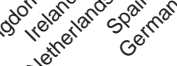

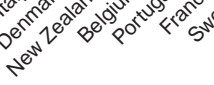

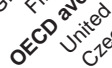

1. The indicator ranges from 0 (least restrictive) to 1 (most restrictive).

2. Includes limits of foreign ownership, restrictions on foreign personnel and operational freedom, screening requirements. Source: See Section on data sources. 
transition countries in particular, restrictions have been substantially eased or even eliminated in sectors such as telecommunications in the last few years.

The most basic observation is that on the whole the OECD countries are now quite open to foreign direct investment inflows. No country has an overall index above 0.4 and most are well below. There are, however, significant differences between countries and across sectors. The most open countries are in Europe. Since the late 1980s, intra-EU FDI flows are almost completely unrestricted and the EEA has also liberalised intra-bloc investment to some extent. In addition, a number of European countries have minimal overt restrictions on inflows from non-EU and non-EEA countries. The countries with the highest levels of overall restrictions are Iceland, Canada, Turkey, Mexico, Australia, Austria and Korea, with restriction scores above 0.25. The United States is a bit below the OECD mean, and Japan is above the OECD mean. The US score may seem surprising. But it should be remembered that the coefficients here do not represent all barriers to doing business but rather discriminatory barriers against foreign firms. The United States may have relatively unregulated markets on the whole but it does have discriminatory barriers to FDI in several sectors. ${ }^{7}$ Excluding screening requirements (Figure 1, panel B) has little effect on the ordering. New Zealand, and to a lesser extent Australia and Spain become relatively more open.

Within Europe, there are some important differences in restrictions. Even the European Union is not a completely unified bloc in terms of policies towards inward FDI. Substantial harmonisation and intra-EU liberalisation has occurred, however. Countries with the lowest levels of restrictions include the United Kingdom, Ireland, the Netherlands, Germany, Denmark, Belgium, and Italy. Norway, Finland and Spain have among the highest restrictions in Europe, with Iceland having the highest of all countries. Overall, however, restrictions in most European countries are well below the OECD average, as further shown in Figure 2 (baseline case). An important reason for this is that the calculations adjust for preferences granted to intra-EU or intra-EEA investment. These adjustments consisted of scaling down European country scores in cases where such intraEuropean preferences were granted. ${ }^{8}$ Figure 2 shows the effect of alternatively including or excluding this adjustment, which could be viewed as understating Europe's restrictions. It could be argued that the European Union should be considered an individual country for these purposes - just as it would be inappropriate to consider the absence of intra-State restrictions in the United States as an indication of freedom of international investment flows. Even after excluding the adjustment, European restrictions are on average below the OECD mean, and several EU countries remain the least restricted in the OECD. Under the alternative scenario of disregarding intra-EU preferences, average EU restrictions now exceed those of the United States, but remain below Japan's. There are substantial differences in the effect of excluding this adjustment on individual European countries, 
Figure 2. Effects of removing intra-European preferences on FDI restrictions ${ }^{1}$

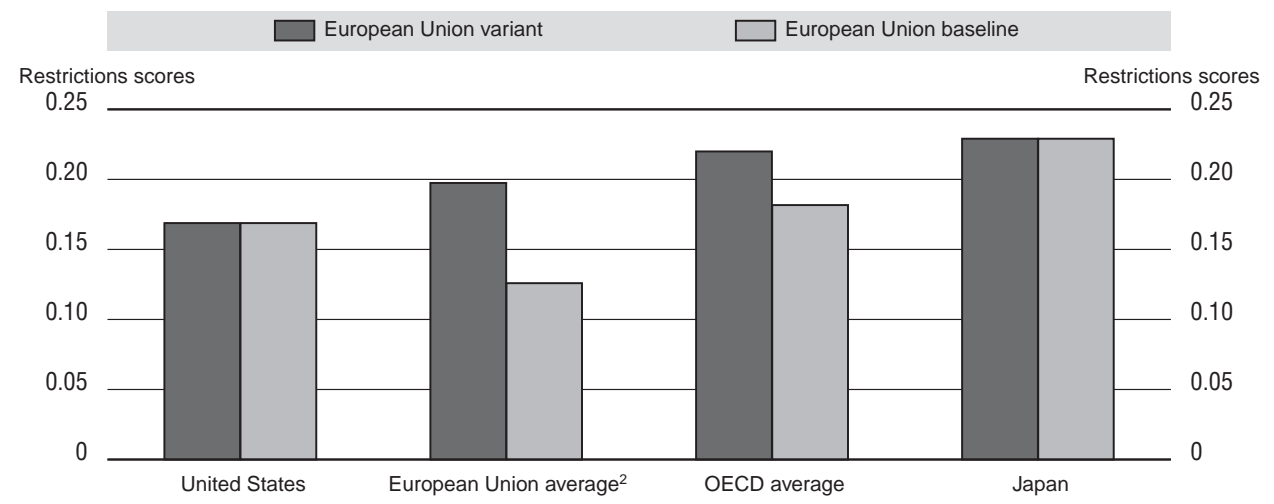

1. The European Union variant ignores intra-European preferences in calculating European restrictions. The European Union baseline incorporates intra-European preferences.

2. Simple average.

Source: See Section on data sources.

as shown in Annex II, although the ranking of countries within Europe by degree of restrictiveness is not greatly altered.

Sectoral scores. It can be seen from Table 3 and Figures 3 and 4 that services are far more restricted than manufacturing. FDI inflows into manufacturing are almost completely unrestricted, aside from economy-wide measures such as screening. In fact, many countries seek to encourage foreign investment in manufacturing. ${ }^{9}$ Construction and hotels and restaurants are also relatively lightly restricted. Some "sensitive sectors", notably telecoms, transport, electricity, and finance are often highly or significantly restricted. Electricity has the highest score, but this derives more from public ownership than overtly discriminatory barriers against foreign investment. Airline transport, fixed line telecommunications, and banking in particular are subject to substantial explicit barriers against FDI in many countries, as shown in Table 3 and Figure 4. Media, such as newspapers and broadcasting, are also highly restricted but were not included in this study due to lack of data for some countries. Figure 4 shows the pattern of restrictions for selected countries in comparison to the OECD average pattern, for the service sectors. Most countries have relatively restricted electricity, transport, telecommunications and finance. The sectoral variation of restrictions is quite marked in the United States where some sectors are almost completely unrestricted whereas others have relatively high levels of restrictions. For some countries such as Iceland and Canada all sector scores are high, usually reflecting the presence of across-the-board screening 
Figure 3. Cross sectoral patterns of FDI restrictions, 1998-2000 ${ }^{1}$

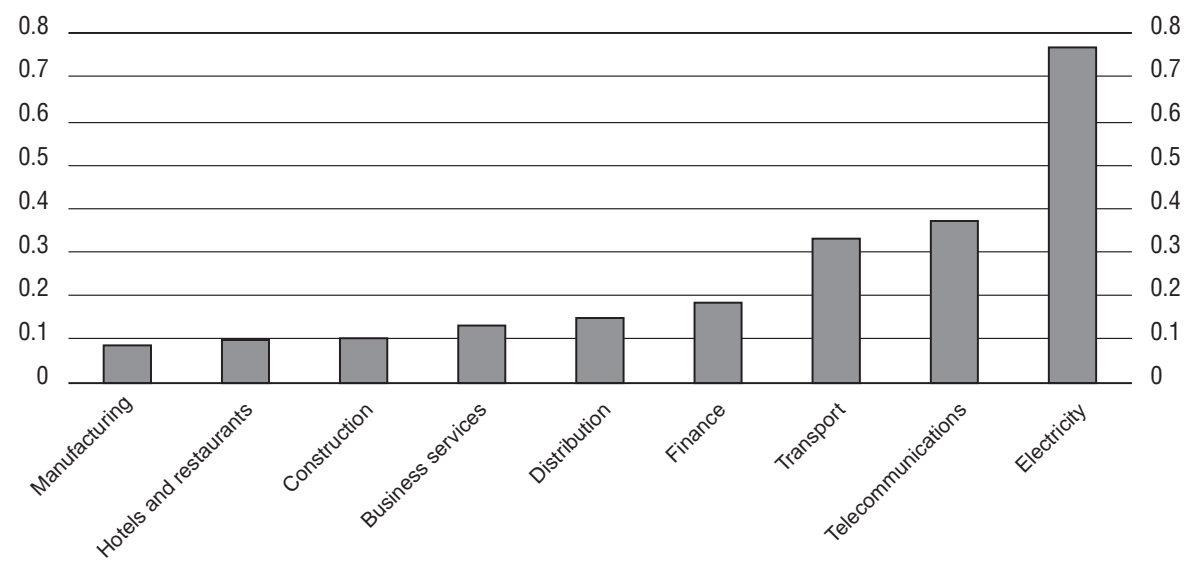

1. The indicator ranges from 0 (least restrictive) to 1 (most restrictive). Source: See Section on data sources.

requirements. Even the most open countries have restrictions on a few sectors, particularly airlines, and some across-the-board restrictions, such as limitations on movement of people.

Decomposition by type of restriction. Figure 5 presents the results for the whole economy by type of restriction: limitations on foreign ownership (equity), screening, and other (management and operational restrictions). The greatest variations are in equity restrictions and screening. The differences in scores between countries reflect both the extent to which countries make use of these measures and their severity.

Some countries, notably in Europe, have no or very limited discriminatory screening of foreign investment. Screening is minor in the United States and Japan. Iceland was deemed to have the most restrictive screening requirement, with Australia, New Zealand, Turkey, Canada, Austria and Spain also having relatively extensive screening.

All countries have equity restrictions, but these vary substantially. These equity restrictions are concentrated in a few sensitive sectors, namely transport, telecommunications, finance and electricity. It is these restrictions that account for the bulk of the sectoral variation in OECD average restrictions observed in Figure 3. Almost all countries have some equity restriction in airline and maritime transport, although the severity varies. The NAFTA countries have among the highest 
Figure 4. Cross-sectoral patterns of FDI restrictions, ${ }^{1}$ 1998-2000
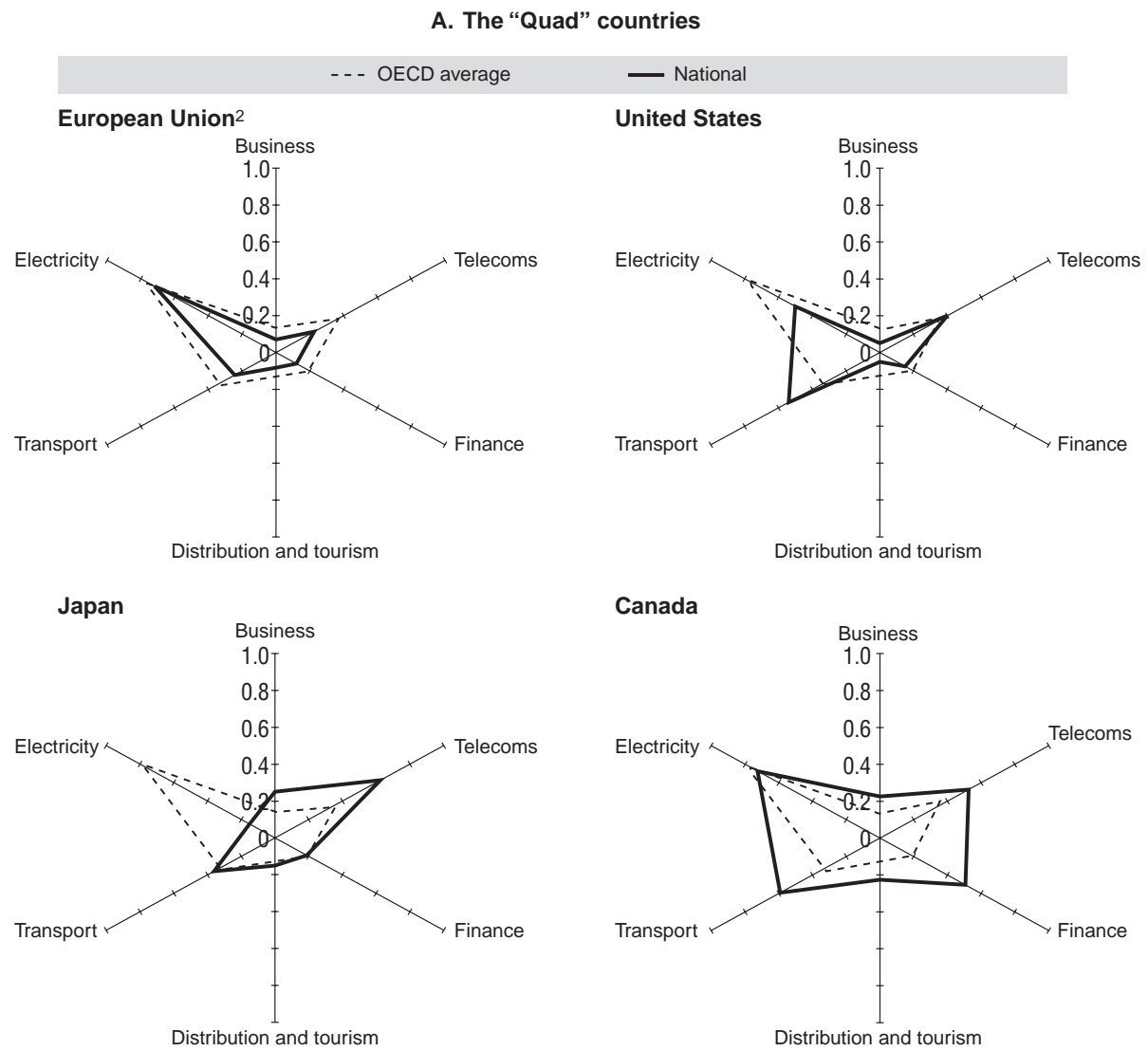

1. The indicator ranges from 0 (least restrictive) to 1 (most restrictive).

2. Average of EU nations.

Source: See Section on data sources.

level of equity restrictions, and there are no intra-NAFTA waivers of these restrictions. Mexico is one of the few countries where these equity restrictions apply to most service sectors. In the United States equity restrictions are confined to a few sectors, but are relatively high in these instances. Turkey and Korea also had relatively stringent equity restrictions in 1998, although some of these have been liberalised since then or are scheduled to be. European equity restrictions are usually but not always waived for investors from other EU or EEA countries, which 102 largely explains the low equity scores in Europe. Also, some of these countries, 
Figure 4. Cross-sectoral patterns of FDI restrictions, ${ }^{1} 1998-2000$ (cont.)

\section{B. Other OECD countries}
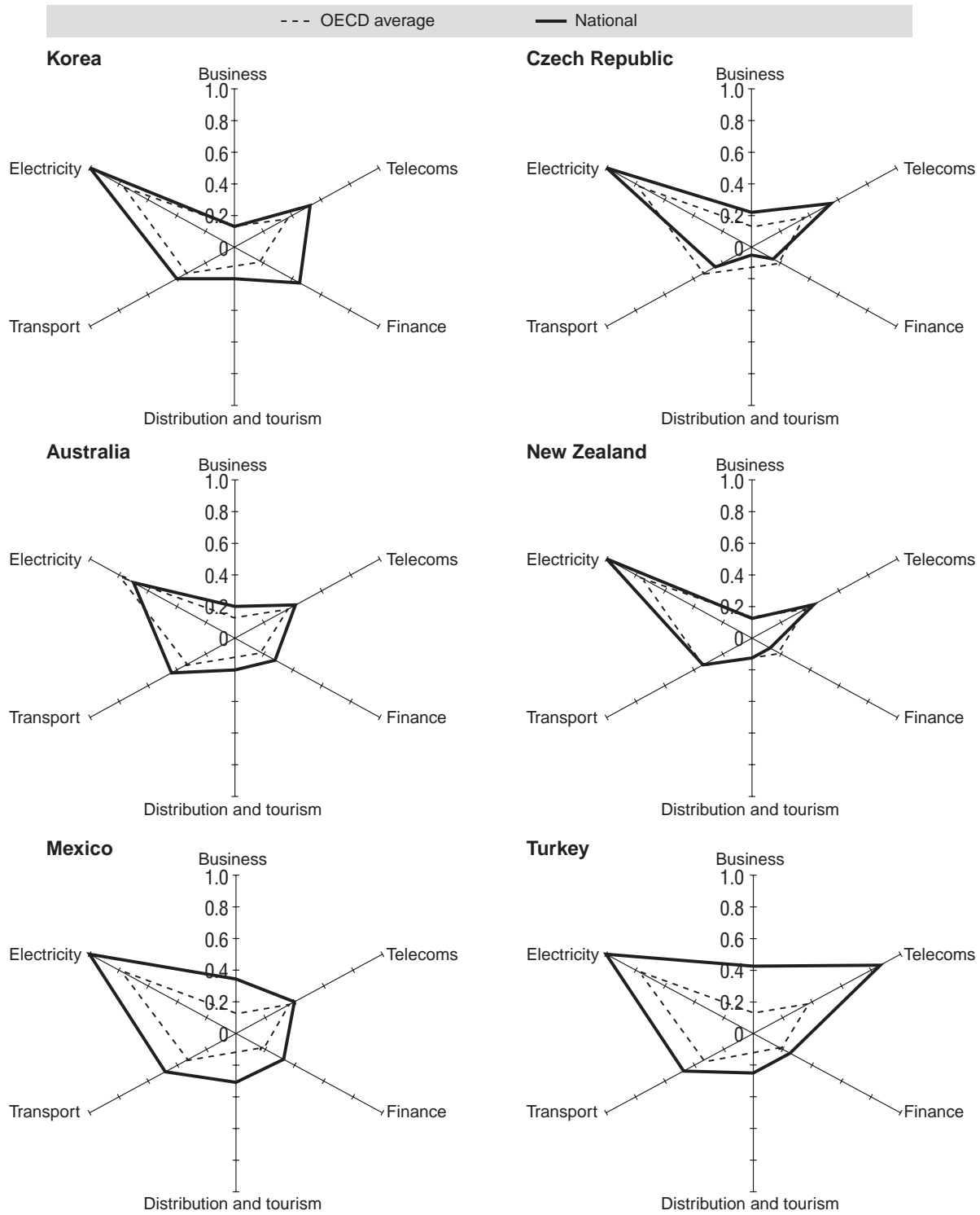

1. The indicator ranges from 0 (least restrictive) to 1 (most restrictive). Source: See Section on data sources. 
Figure 5. FDI restrictions in OECD countries, 1998-2000: breakdown by type of restriction ${ }^{1}$

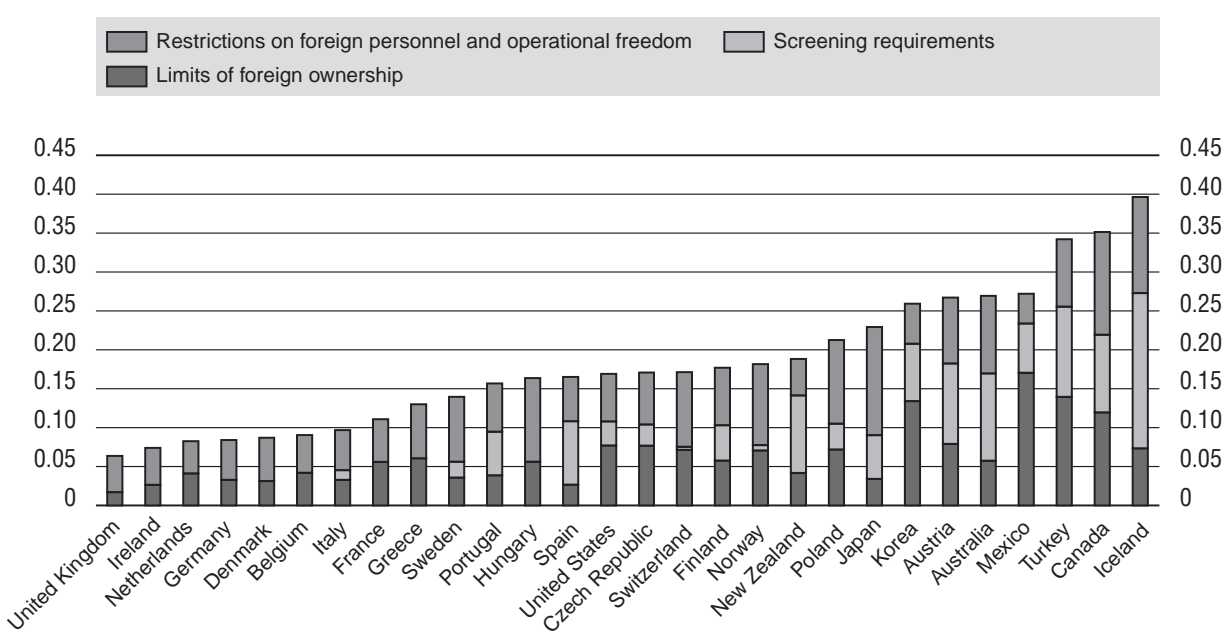

1. The indicator ranges from 0 (least restrictive) to 1 (most restrictive). Source: OECD.

such as Ireland, the Netherlands, the United Kingdom, Denmark, and Germany, have hardly any such restrictions to begin with.

Japan has the highest level of "other" restrictions, partly reflecting the allegations of lack of transparency and procedural delays documented in some sectors in USTR and EU reports. This is one of the instances where intangible barriers to FDI were taken into account in the scoring. Similar allegations by USTR about European telecommunications markets and Japan's METI about the United States were also factored into the US score.

The effect of switching to value-added weights (each sector's share of GDP) in aggregating sectoral restrictions scores had minimal effects for most countries, with the United States being the major exception. With value added weights, most countries FDI restriction scores fall modestly as value-added weights tend to give greater weight to services that are not heavily restricted such as business services, distribution, and hotels and restaurants. Since United States restrictions are unusually concentrated in a few sectors, the use of value added weights significantly lowers the US restrictions score. A number of European countries, however, still have lower scores than the United States. See Annex II $\lcm{104}$ for further results. 


\section{Time series results}

The cross-section restriction measures were extrapolated backward in time using OECD documents. This could only be done for long-standing OECD countries, however, and the findings should be viewed with greater caution than the cross-section results, due to lesser available information and reliance on a less varied set of sources. The results are found in Table 4 and Figure 6.

It can be observed that restrictions on FDI have decreased markedly over time for most countries. A major exception is the United States, which in the early 1980s was one of the most open countries but was in the middle of the pack by the late 1990s. This reflects the fact that there have been almost no changes in the United States, while most other countries have greatly liberalised access for foreign investors. In the early 1980s, a number of countries had total scores in the

Table 4. Indices of FDI restrictions over time

Total economy

\begin{tabular}{llll}
\hline & 1980 & 1990 & 2000 \\
\cline { 2 - 4 } Australia & 0.460 & 0.332 & 0.270 \\
Austria & 0.432 & 0.432 & 0.268 \\
Belgium & 0.291 & 0.291 & 0.091 \\
Canada & 0.484 & 0.379 & 0.352 \\
Denmark & 0.246 & 0.161 & 0.087 \\
Finland & 0.521 & 0.463 & 0.177 \\
France & 0.487 & 0.233 & 0.111 \\
Germany & 0.181 & 0.174 & 0.084 \\
Greece & 0.404 & 0.332 & 0.130 \\
Iceland & 0.600 & 0.481 & 0.390 \\
Ireland & 0.345 & 0.250 & 0.074 \\
Italy & 0.264 & 0.264 & 0.097 \\
Japan & 0.251 & 0.237 & 0.230 \\
Netherlands & 0.264 & 0.243 & 0.083 \\
New Zealand & 0.396 & 0.237 & 0.189 \\
Norway & 0.510 & 0.466 & 0.182 \\
Portugal & 0.569 & 0.223 & 0.157 \\
Spain & 0.336 & 0.230 & 0.165 \\
Sweden & 0.429 & 0.335 & 0.140 \\
Switzerland & 0.306 & 0.278 & 0.172 \\
Turkey & 0.507 & 0.391 & 0.338 \\
United Kingdom & 0.215 & 0.167 & 0.064 \\
United States & 0.171 & 0.170 & 0.169 \\
Mean & 0.377 & 0.294 & 0.175 \\
Maximum & 0.600 & 0.481 & 0.390 \\
Standard deviation & 0.128 & 0.101 & 0.094 \\
\hline
\end{tabular}

Source: See section on data sources. 
Figure 6. FDI restrictions in OECD countries, 1980-2000 ${ }^{1}$

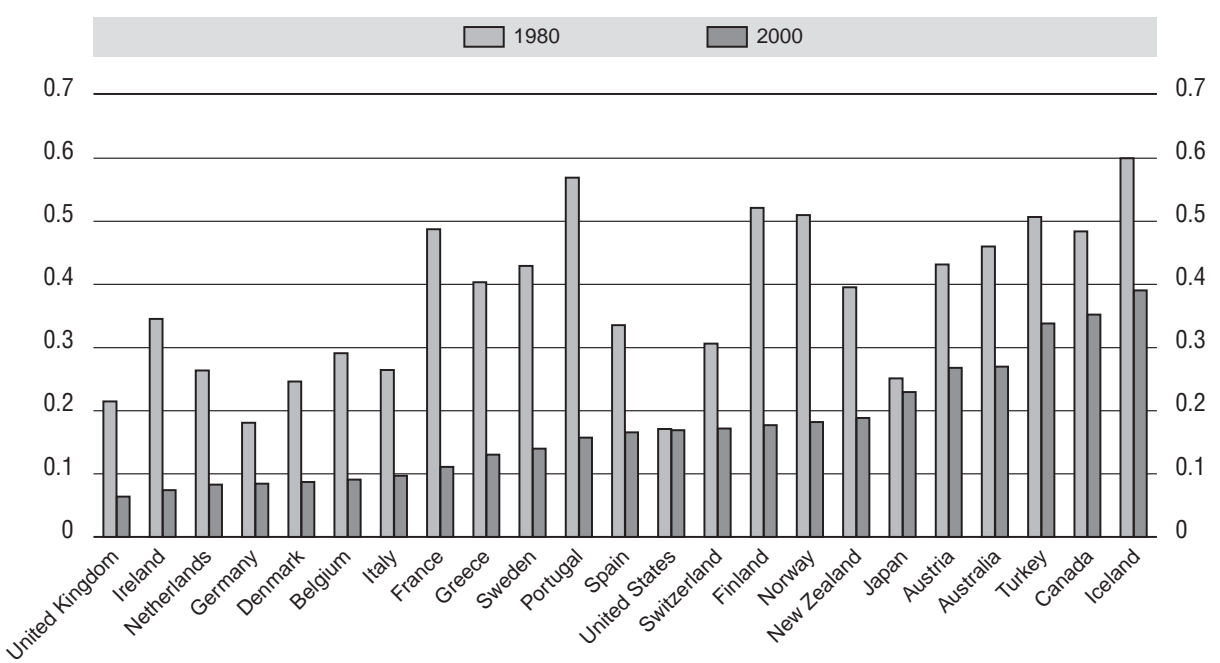

1. The indicator ranges from 0 (least restrictive) to 1 (most restrictive).

Source: See Section on data sources.

0.4 to 0.6 range. The changes have been particularly dramatic in several European countries, notably Portugal, France, Norway, and Finland.

The liberalisation of inward foreign investment reflects a number of trends. First, as noted earlier, the European Union has greatly liberalised intra-EU FDI, and since about half of FDI into the EU is from other EU countries, this is tantamount to a substantial overall liberalisation. Second, most countries have liberalised both their economy-wide and sector-specific restrictions, to varying degrees. Third, the prevalence of public monopoly in sectors such as telecoms, banking and transport has greatly diminished as privatisation has been pursued throughout the OECD. ${ }^{10}$ This is one reason why FDI restrictions have changed less in the United States than elsewhere: in the US there was much less to privatise and demonopolise to begin with.

Figure 7 shows the time series for selected sectors. Air transport and telecoms were almost completely closed to FDI in the early 1980s and are still more restricted than other sectors, as noted in the previous section. But the change has been even more dramatic in these industries than for the economy as a whole. Figure 7 also shows that while there has been a steady trend towards liberalisation, the pace accelerated in the 1990s. 
Figure 7. FDI restrictions over time in selected sectors, 1981-1998

OECD average $^{2}$

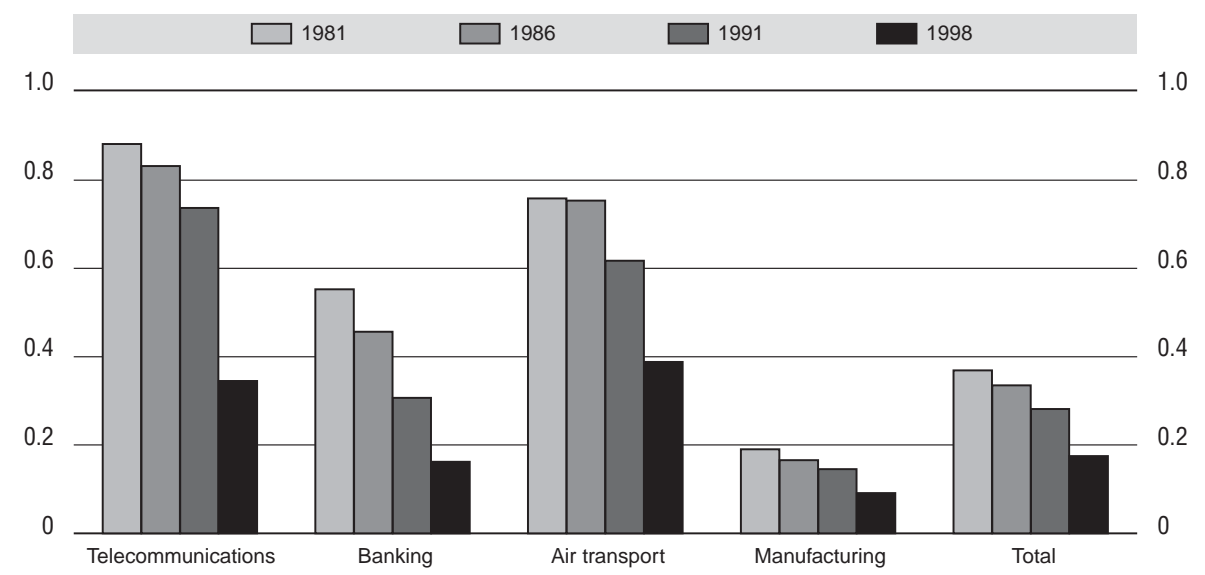

1. The indicator ranges from 0 (least restrictive) to 1 (most restrictive).

2. Average for 23 OECD countries.

Source: See Section on data sources.

\section{CONCLUSIONS}

The last two decades, and especially the 1990s, have witnessed significant liberalisation in FDI restrictions. OECD countries are now generally open to inward FDI, although there remain substantial differences between countries and across industries. The most open countries are now in Europe, at least as far as statutory restrictions are concerned. The preponderance of remaining restrictions is in services, with almost no overt restrictions in manufacturing. On the contrary, many countries provide incentives for manufacturing investment, although systematic evidence is lacking.

This paper has not evaluated the effects of restrictions, but Nicoletti et al. (2003) uses the findings of this paper in an econometric model of FDI, and finds a statistically important effect of the computed restrictions on FDI patterns.

The most heavily restricted sectors are those that are highly sensitive to national security or national sovereignty considerations: telecommunications, air and maritime transport, finance, public utilities, and media (the latter not considered in this study). Whether or not these restrictions are justified on social costbenefit grounds is a difficult issue beyond the scope of this paper, involving tradeoffs between national sovereignty and economic efficiency. From an eco- 
nomic point of view, non-discrimination between domestic and foreign investors is generally the best policy in the absence of a clear-cut market failure or threat to national security. Liberalisation of remaining restrictions can be facilitated by continued discussions at the OECD and the WTO on multilateral rules for investment. Further liberalization of restrictions discriminating against FDI could be accompanied by efforts to discipline incentives that discriminate in favour of FDI.

This study has focused on statutory restrictions. Informal public or private barriers remain mostly unaccounted for in the measures provided here. Future research should focus on such non-transparent practices and institutional obstacles. For example, free float in stock market capitalisation could be used as a proxy for effective openness to acquisitions of minority shareholdings. The ongoing development of codes, guidelines and best practices in areas with direct impact on public and private sector governance practices may enhance the possibilities of pin-pointing and measuring non-conforming practices that affect relative openness to FDI. 


\section{NOTES}

1. A number of bills were considered by the US Congress but the more restrictive measures did not pass, reflecting the still-strong support for openness to foreign investment in the United States. The Exon-Florio Provision of the 1988 Omnibus Trade Act gave the President the authority to restrict foreign investment for national security reasons. This provision gave rise to considerable alarm, but the grounds for restricting FDI are narrow and specific and it has almost never been invoked. See OECD (1992, p. 22) and Graham and Krugman (1995).

2. See Golub (2003) for further discussion.

3. The GATS schedules reflect commitments as of January 2000. Subsequent policy changes are not incorporated.

4. See OECD (2002) for further discussion of the Code.

5. The OECD countries covered by this FDI study but not included in the APC studies are the Czech Republic, Hungary, Poland, and Iceland.

6. For example, the USTR alleges "exclusionary practices" in Japan in some sectors and discriminatory barriers against US firms in some European countries' telecommunications markets. Similarly, METI cites "procedural delays" in the issuance of operating licenses in telecommunications in the United States. In such cases, restriction scores were increased by 0.1 .

7. Switching to value-added weights, however, significantly lowers the US score, as discussed below.

8. Where restrictions on intra-European investments are waived, the restriction is weighted by 0.44 , reflecting the fact that 56 per cent of FDI inflows into European countries were intra-European in 1998. This could overstate the effect of the waiver to the extent that this waiver endogenously raises the share of intra-European FDI.

9. In manufacturing, social and regulatory policies such as health and safety regulations, environmental standards, and technical standards undoubtedly also can act as indirect restrictions, but these are not considered here.

10. Electricity, however, has remained under public ownership in many countries. 


\section{Annex I}

COMPARISONS WITH HARDIN AND HOLMES (1997)

This annex provides more detail on the computation of the FDI Restrictions Indices, in particular comparing the Hardin-Holmes $(\mathrm{HH})$ methodology to the one adopted here. As noted in the text, the weights used here are broadly similar to those of $\mathrm{HH}$, in particular placing a high importance on equity restrictions. The HH weights are shown in Table A.1.

The main difference is that $\mathrm{HH}$ distinguish between restrictions on all firms from those on existing firms only (mergers and acquisitions). But this distinction is of little consequence as the bulk of FDI in OECD countries concerns existing firms. Also, few OECD countries distinguish between green-field and mergers and acquisitions in their statutory FDI restrictions.

\section{Table A.1. Hardin and Holmes coefficients on FDI restrictions}

Maximum 1.0

\begin{tabular}{lr}
\hline Type of restriction & Scores \\
\hline Foreign equity limits on all firms & 1 \\
$\quad$ No foreign equity allowed & 0.5 \\
$0-49 \%$ foreign equity allowed & 0.25 \\
$50-99 \%$ foreign equity allowed & 0.5 \\
Foreign equity limits on existing firms, none on Greenfield & 0.25 \\
$\quad$ No foreign equity allowed & 0.125 \\
$0-49 \%$ foreign equity allowed & 0.1 \\
$50-99 \%$ foreign equity allowed & 0.075 \\
Screening and approval & 0.05 \\
Investor required to demonstrate net economic benefits & \\
Approval unless contrary to national interest & 0.2 \\
Notification (pre or post) & 0.1 \\
Control and management restrictions & \\
All firms & 0.2 \\
Existing firms, none for Greenfield & 0.1 \\
Input and Operational Restrictions & \\
All firms & \\
Existing firms, none for Greenfield & \\
Total & \\
\hline Source: Hardin and Holmes (1997). & \\
\hline
\end{tabular}


On the other hand, the equity limits were broken down into smaller ranges. In cases where no equity restriction was listed, but the country had no GATS commitment, the lack of equity restrictions is considered "unbound" and a score of 0.05 was given. Second, the HH weight on screening seemed low, especially in the case where the burden of proof is on the investor to demonstrate benefit, and was therefore raised. Third, in aggregating sub-sectors $\mathrm{HH}$ use simple rather than weighted averages. Instead this study weights by economic importance, using FDI weights for the OECD as a whole. Fourth, in HH multiple restrictions of the same type are counted only once, which could possibly lead to an underestimate of FDI restrictiveness for countries that apply multiple restrictions, as they note. With a somewhat more detailed breakdown of the types of restrictions here, following other studies of the Australian Productivity Commission, this problem is partially circumvented. These include restrictions on the residency and nationality of board members and duration of permissible stay for expatriate personnel. Finally, this study covers a smaller set of services industries, but includes electricity and manufacturing, a larger group of countries and a richer set of data sources.

HH limited their study to APEC countries. Several other APC studies examined particular sectors: telecommunications, banking, maritime services, professional services and distribution. The APC studies evaluated all modes of service delivery, rather than just FDI, and comparison with this study therefore required re-weighting the components of the APC scores. After doing so, the correlation coefficient between this study's results and those of the APC for telecoms, banking, and maritime services were quite high at $0.58,0.57$ and 0.56 respectively. For distribution and business services it is lower but still positive $(0.28$ and 0.10 respectively). The low correlation for professional services is not surprising given that commercial presence plays a minor role in the APC weighting indices and therefore is illsuited for the purpose of measuring FDI restrictions, even after attempts to re-weight them. Annex I of Golub (2003) provides a more detailed comparison. 


\section{Annex II}

\section{SENSITIVITY ANALYSIS TO CHANGES IN ASSUMPTIONS}

Intra-European FDI liberalisation. Figure A.1 shows the effects of removing of intra-European FDI preferences, as discussed in the text. The effects are substantial, although they vary somewhat by country. For some countries, e.g. the United Kingdom, the Netherlands, Ireland, Sweden, and Greece, removing the effects of FDI preferences roughly doubles the country's restrictions score. Intra-European preferences are weakest in Austria and also relatively small in Spain and Portugal, reflecting differences in the extent to which preferences are granted to other European countries. For example, Austria's screening requirements apply to all foreign investments, including those from other European countries.

Figure A.1. Effects of removing intra-European preferences on FDI restrictions, 1998-2000'

European countries

0.3

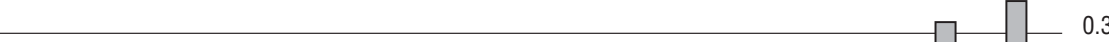

0.2

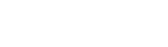

2

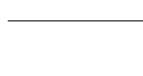

0.1

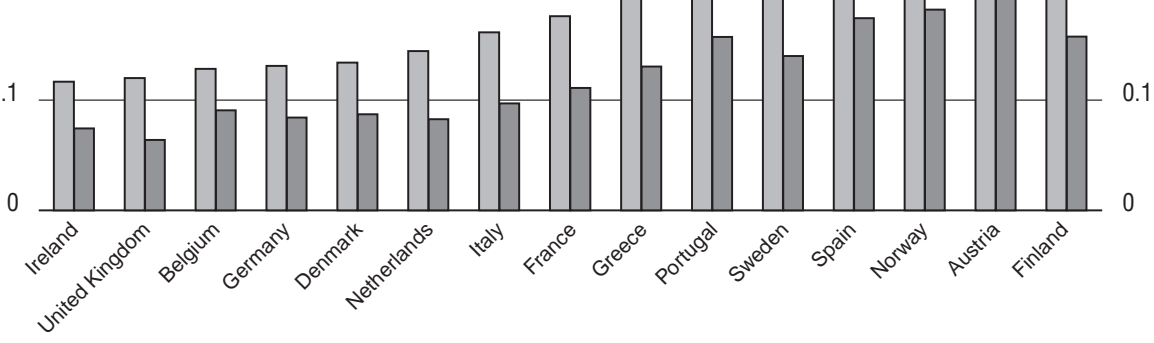

1. The European Union variant ignores intra-European preferences in calculating European restrictions. The European Union baseline incorporates intra-European preferences.

112 Source: See Section on data sources. 
Table A.2. Sector weights

\begin{tabular}{lccc}
\hline & FDI & Adjusted FDI ${ }^{1}$ & Value added \\
\cline { 2 - 3 } Business & 0.18 & 0.18 & 0.22 \\
Telecommunications & 0.05 & 0.04 & 0.04 \\
Construction & 0.01 & 0.02 & 0.08 \\
Wholesale, retail & 0.13 & 0.09 & 0.17 \\
Finance & 0.25 & 0.16 & 0.07 \\
Hotels, restaurants & 0.01 & 0.01 & 0.04 \\
Transport & 0.01 & 0.14 & 0.07 \\
Electricity & 0.02 & 0.02 & 0.04 \\
Manufacturing & 0.35 & 0.35 & 0.28 \\
Total & 1.00 & 1.00 & 1.00 \\
\hline
\end{tabular}

1. For the service sectors, an average of FDI and trade weights; for manufacturing, FDI weight.

Source: OECD.

Alternative Sector Weights. Table A.2. shows alternative weights for aggregating the sectoral restrictions. The use of FDI weights raises a problem of endogeneity: highly restricted sectors may experience less FDI and hence receive too low a weight. As noted above, services are much more highly restricted than manufacturing, so any such problem of endogeneity is concentrated in the former. To deal with this problem, for the service sectors, an average of FDI and trade weights was employed. The inclusion of cross-border trade in the weighting scheme may be justified insofar as cross-border trade can substitute for FDI when the latter is restricted. As an alternative, Figure A.2 shows the effects of using value-added weights

Figure A.2. FDI restrictions measures under alternative weighting methods

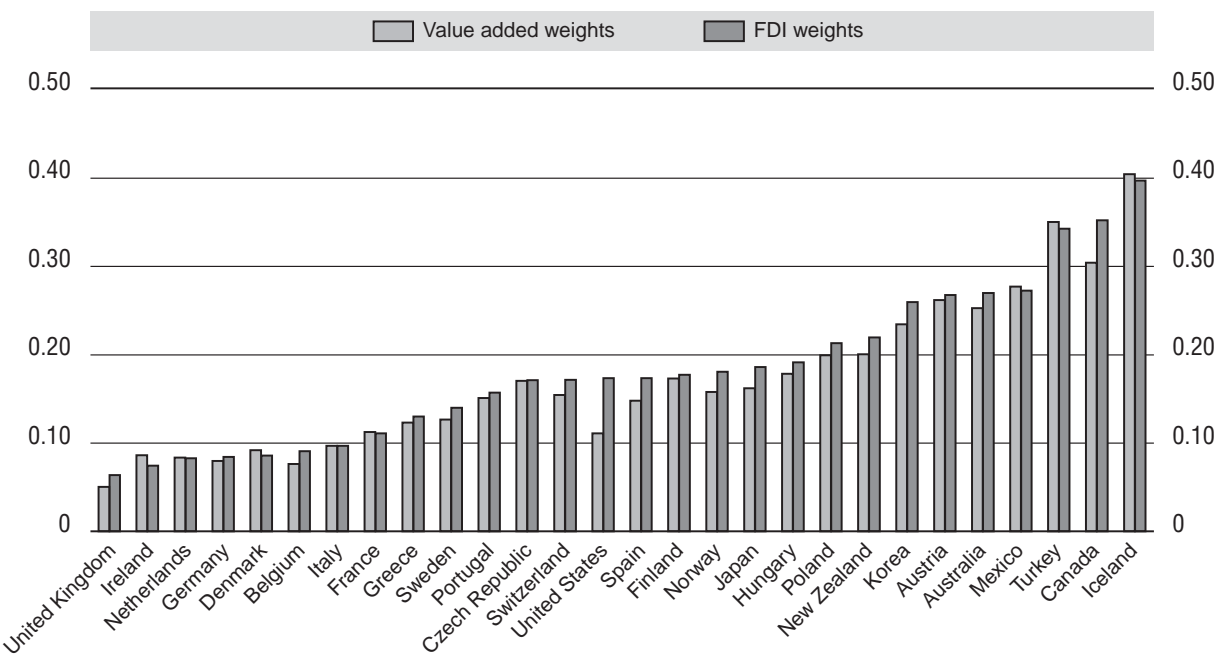

Source: See Section on data sources. 
rather than FDI weights in aggregating the sectoral FDI restrictions measures into an aggregate measure for the economy. As noted in the text, the use of FDI weights tends to slightly lower most countries' restriction scores. The largest effect is on the United States, which has a substantial decline in restrictiveness. Canada also has a moderate decline in its restriction score. In all other countries, the effect is minimal. The large effect on the United States reflects the unusually skewed pattern of restrictions shown in Figure 4. 


\section{BIBLIOGRAPHY}

EUROPEAN COMMISSION (2003), "Bilateral Trade Relations with Countries...", http:// europa.eu.int/comm/trade/bilateral/euta.htm

FINDLAY, C. and T. WARREN (eds.) (2000), Impediments to Trade in Services: Measurement and Policy Implications, Routledge: New York and London.

GOLUB, S. (2003), "Measures of Restrictions on Inward Foreign Direct Investment for OECD Countries", OECD Economics Department Working Paper No. 357.

GRAHAM, E.M. (2000), Fighting the Wrong Enemy, Institute for International Economics, Washington.

GRAHAM, E.M. and P.R. KRUGMAN (1995), Foreign Direct Investment in the United States, Institute for International Economics, Washington.

HOEKMAN, B. (1995), "Assessing the General Agreement on Trade in Services", In Martin, W. and L.A. Winters (eds.), The Uruguay Round and the Developing Countries, World Bank Discussion Paper 307.

HARDIN, A. and L. HOLMES (1997), "Service Trade and Foreign Direct Investment", Australian Productivity Commission, (www.pc.gov.au/ic/research/information/servtrad/index.html).

HARDIN, A. and L. HOLMES (2002), "Measuring and Modelling Barriers to FDI", in Bora, B. (ed.) Foreign Direct Investment: Research Issues, Routledge, London.

KALIJARAN, K. (2000), "Restrictions on Trade in Distribution Services", Australian Productivity Commission, August 2000.

KOULEN, M., M. GESTRIN and P. SAUVÉ (2002), “Trade, Investment and the WTO: Issues and Options", mimeo, OECD 2002.

MARKUSEN, J.R. and K. MASKUS (2001), "General Equilibrium Approaches to the Multinational Firm: A Review of Theory and Evidence", NBER Working Paper No. 8344, June.

MINISTRY OF ECONOMY, TRADE, AND INDUSTRY (JAPAN) (2003), Report on the WTO Consistency of Trade Policies by Major Trading Partners, www.meti.go.jp/english/report/index.html

McGUIRE, G. (2002), "Methodologies for Measuring Restrictions on Trade in Services", paper presented at OECD-World Bank Services Experts Meeting, Paris, March.

NGUYEN-HONG, D. (2000), "Restrictions on Trade in Professional Services", Australian Productivity Commission, August.

NICOLETTI, G., S. GOLUB, D. HAJKOVA, D. MIRZA and K.-Y. YOO (2003), "The Influence of Policies on Trade and Foreign Direct Investment", OECD Economic Studies, this issue.

OECD (various years), OECD Code of Liberalisation of Capital Movements, Paris.

OECD (various countries and dates), OECD Reviews of Foreign Direct Investment, Paris.

OECD, (1982), Controls and Impediments Affecting Inward Direct Investment in OECD Member Countries, Paris. 
OECD, (1987), Controls and Impediments Affecting Inward Direct Investment in OECD Member Countries, Paris.

OECD, (1992), International Direct Investment: Policies and Trends in the 1980s, Paris.

OECD, (2002a), Forty Years' Experience with the OECD Code of Liberalisation of Capital Movements, Paris.

OECD (2002b), Foreign Direct Investment and Development: Where Do We Stand?, Paris.

OECD (2002c), Foreign Direct Investment for Development - Maximising benefits, minimising cost, Paris.

PRICE-WATERHOUSE-COOPERS (2001), Doing Business and Investing in Countries World-wide, CD-ROM.

ROBERTSON, D. (2002), “Multilateral Investment Rules”, in Bora, B. (ed.) Foreign Direct Investment: Research Issues, Routledge, London.

SAUVÉ, P. and K. STEINFATT (in progress), "Assessing the scope for further investment regime liberalisation: An analysis based on revealed liberalisation preferences", OECD.

SAUVÉ, P. and C. WILKIE (2000), "Investment Liberalisation in GATS" in Sauvé, P. and R.M. Stern (eds.), GATS 2000: New Directions in Services Trade Liberalisation, Brookings, Washington.

UNCTAD (1996), World Investment Report, Geneva.

UNITED STATES SPECIAL TRADE REPRESENTATIVE (2003), National Trade Estimate Report on Foreign Trade Barriers, www.ustr.gov/reports/index.shtml

WEI, S.J. (2000), "Negative Alchemy? Corruption and Composition of Capital Flows", OECD Development Centre Technical Paper, No. 165, October.

WORLD TRADE ORGANISATION (2002), WTO Services Database, http://tsdb.wto.org/wto/WTOHomepublic.htm

YOO, K.-Y. (2003), "Corporate Taxation of Foreign Direct Investment Income 1991-2001", OECD Economic Department Working Papers No. 365, Paris. 